\title{
СПЕЦИАЛЬНЫЕ МЕРЫ ПРЕДУПРЕЖДЕНИЯ КОРРУПЦИИ В ПРАВООХРАНИТЕЛЬНОЙ СИСТЕМЕ
}

\author{
Багмет A.M.
}

\begin{abstract}
Аннотация: Предметом исследования данной статьи выступают специальные меры по предупреждению коррупиии в правоохранительных органах. Автором отмечается, что основной акцент должен быть сделан на разработке и осуществлении системы мер упреждающего характера. Отмечаются в правоохранительных органах системные меры профилактики и противодействия коррупиии, которые охватывают все этапы службы сотрудника - от поступления на службу до увольнения в отставку. Подчеркивается особое значение виктимологического направления в структуре специально-криминологической предупредительной работы. Методология исследования представлена следующей группой методов: системный, сравнительный, структурно-функииональный, метод анализа и синтеза, метод причинно-следственной связи. Основным вкладом автора является глубинное выявление и характеристика спеииальных мер, призванных противодействовать коррупционным явлениям в правоохранительных органах. Анализ специальных мер предупреждения коррупиионной преступности в правоохранительной системе показывает, что основной акиент в антикоррупционной борьбе в правоохранительной системе должен быть сделан на разработке и осуществлении системы мер упреждающего характера.
\end{abstract}

Ключевые слова: Предупреждение, система мер, коррупция, должностные преступления, выявление, деятельность, профилактика, правоохранительные органы, состояние, сфера.

Особая роль правоохранительных органов определяется разнообразием и широтой компетенции, обширным спектром полномочий по осуществлению специфичной деятельности, в частности, административно-юрисдикционной, уголовно-процессуальной, оперативно-розыскной, по противодействию правонарушениям и преступлениям [1].

Ни у кого не вызывает сомнение, что правоохранительные органы нуждаются в тщательном государственном и общественном контроле на предмет профилактики коррупционности.

Однако выявление факторов, влияющих на криминальное поведение сотрудников правоохранительных органов, а также изучение личности данной категории граждан не является самоцелью, а выступает необходимым условием целенаправленной борьбы с опасными, подрывающими авторитет власти преступлениями. Борьба с коррупционной преступностью сотруд- 
ников правоохранительных органов не может быть сведена только к выявлению и наказанию виновных. Основной акцент должен быть сделан на разработке и осуществлении системы мер упреждающего характера [2].

На первоначальном этапе следует повысить эффективность системы отбора кандидатов на службу в правоохранительные органы. К сожалению, в настоящее время проблема укомплектования служб и подразделений органов внутренних дел высококвалифицированными кадрами является одной из острых. Достаточно низкий престиж службы в правоохранительных органах, отсутствие надёжных социально-правовых гарантий сотрудников, неадекватное материальное стимулирование их труда не способствуют созданию объективных условий для конкурсного набора кандидатов; отсутствие реального конкурса приводит к тому, что часть кандидатов, поступивших на службу в правоохранительные органы, не отвечает предъявляемым требованиям [3].

По моему мнению, превентивная политика должна осуществляться с учетом позитивного опыта, накопленного в советский период развития государства, когда в стране существовала разветвленная и влиятельная система органов народного и партийного контроля, обладавших широкими полномочиями. В то же время необходимо помнить, что на уровне специального предупреждения коррупции сотрудников правоохранительных органов традиционный набор профилактических мер недостаточно эффективен, а в ряде случаев неприемлем.

Не вызывает сомнений позиция отечественных ученых, что для профилактики коррупционного поведения сотрудников правоохранительных органов необходимо создание системы своевременного выявления среди них лиц, склонных к совершению преступлений.

С учетом систематизации ряда факторов, характеризующих поведение сотрудников правоохранительных органов, как при выполнении служебных обязанностей, так и в условиях проведения отдыха или досуга, можно не только выявлять степень его личностных деформаций, но и прогнозировать возможность совершения противоправных проступков. Критериями, позволяющими из общего числа сотрудников того или иного подразделения выявить субъекты повышенного риска, могут выступать следующие данные:

- совместное проведение досуга с членами организованных преступных формирований;

- поддержание неделовых контактов с лицами, обоснованно подозреваемыми в противоправной деятельности;

- приобретение дорогостоящих предметов роскоши, частые поездки за рубеж, наличие крупных сумм денег;

- непринятие мер по явным фактам преступных действий отдельных лиц, консультирование лиц, пытающихся уйти от уголовной ответственности;

- неделовые связи с «разрабатываемым контингентом»;

- частые невыходы на службу, регулярное предъявление больничных листов, постоянные перемены места службы и т.д.

В настоящее время в правоохранительных органах предусмотрены системные меры профилактики и противодействия коррупции, охватывающие все этапы службы сотрудника-от поступления на службу до увольнения в отставку. В должностные обязанности всех руководителей вменены требования по проведению с каждым сотрудником индивидуально-воспитательной работы. Грамотное, творческое сочетание воспитательных мер с усилением контроля за поведением сотрудников правоохранительных органов на службе и в быту, своевременное решение всех вопросов их социальной защищенности, безусловно, приведет к большей эффективности, чем лишь жесткие карательные меры.

Например, в МВД России разработаны антикоррупционные стандарты поведения сотрудников силовых структур, являющиеся составной частью Кодекса профессиональной этики. Начинает действовать институт поручительства при поступлении кандидатов на службу в ОВД, на учёбу в ведомственные образовательные учреждения, при назначении на вышестоящие руководящие должности. 
Не вызывает сомнение необходимости специального обучения сотрудников правоохранительных органов, с целью формирования у обучающихся антикоррупционного мышления и антикоррупционного поведения [4].

В частности, в Академии Следственного комитета Российской Федерации на курсах повышения квалификации решаются следующие основные задачи:

- формирование у обучающихся умений и навыков анализа и оценки данных о состоянии коррупции в правоохранительных органах, ее прогнозировании, выяснения причин и выработки мер по противодействию ей;

- получение слушателями общего представления о состоянии коррупции в правоохранительных органах;

- формирование потребности в противодействии коррупции и непринятии коррупции как средства достижения личных либо корпоративных целей.

При этом в процессе изучения спецкурса по антикоррупционной деятельности обучающиеся должны приобрести следующие навыки:

- иметь свободное от идеологических штампов представление о коррупции в правоохранительных органах, её причинах и пределах возможного воздействия на неё;

- уметь адекватно интерпретировать результаты научных исследований о состоянии коррупции в правоохранительных органах;

- знать особенности и закономерности проявления коррупции в различных сферах жизнедеятельности, в том числе и правоохранительной;

- знать и уметь использовать приемы противодействия коррупционному поведению;

- владеть приемами и методами исследования коррупции как социального явления;

- уметь планировать антикоррупционные мероприятия в рамках правоохранительных органов;

- четко представлять критерии эффективности антикоррупционной деятельности в правоохранительных органах.

По мнению специалистов в предупреждении коррупционных преступлений, совершаемых сотрудниками правоохранительных органов, немалую часть должна занимать виктимологическая профилактика, так как потерпевшие от противоправных действий сотрудников правоохранительных органов зачастую сами провоцируют последних.

Виктимологическое направление в структуре специально-криминологической предупредительной работы обладает определенной спецификой:

- виктимологическая профилактика имеет свой самостоятельный объект позитивного воздействия - реальных и потенциальных жертв преступлений;

- информационное обеспечение виктимологической профилактики помимо использования общих для нее и для криминологической профилактики информационных источников связано с применением специальных схем выявления ее объектов (в частности, с использованием классификаций жертв и виктимноопасных ситуаций);

- методы виктимологической профилактики и формы, в которых она осуществляется, основаны в первую очередь на убеждении;

- общая и индивидуальная виктимологическая профилактика осуществляется также на основе широкого использования возможностей взаимопомощи населения;

- виктимологическая профилактика осуществляется также путем нейтрализации опасных ситуаций, в которых еще не проявились возможные причинители вреда и имеются условия, позволяющие ориентироваться лишь на определенные типы потенциальных жертв;

- виктимологическая профилактика имеет своей задачей предотвращение так называемых «инверсионных преступлений», в которых происходит смена ролей «преступник-жертва» путем воздействия на потенциальных жертв;

- виктимологическая профилактика преступлений имеет и организационные особенности, связанные со специальной подготовкой сотрудников правоохранительных органов, созданием специальных учетов виктимологически уязвимых объектов, организацией специальной 
психолого-педагогической службы органов внутренних дел.

Мероприятия виктимологической профилактики коррупции могут включать в себя:

- изготовление и распространение специальных брошюр-предостережений о том, как уберечься от коррупции и не стать жертвой этого преступления;

- извещение граждан через средства массовой информации об имевших на территории региона фактах совершения коррупционных преступлений, типичных действиях коррупционеров и о том, как следует поступать гражданам в подобных случаях;

- оказание практической помощи гражданам в технической и физической защите от данного вида преступлений;

- разработка и внедрение специальных средств, позволяющих обеспечить экстренный вызов работников правоохранительных органов;

- проведение целенаправленных бесед с родителями, педагогами, школьниками, студентами о том, как следует вести себя и что де- лать в случае, когда граждан пытаются втянуть в коррупционные отношения;

- проведение бесед с теми категориями населения, социальное положение и профессиональная деятельность которых вызывают повышенный интерес коррупционеров.

Таким образом, анализ специальных мер предупреждения коррупционной преступности в правоохранительной системе показывает, что основной акцент в антикоррупционной борьбе в правоохранительной системе должен быть сделан на разработке и осуществлении системы мер упреждающего характера. Кроме того, необходимо повысить эффективность системы отбора кандидатов на службу в правоохранительные органы, создать систему своевременного выявления в них сотрудников, склонных к совершению коррупционных преступлений, ввести специальные обучающие курсы по формированию антикоррупционного мышления и поведения, разработать виктимологическую антикоррупционную профилактику.

\section{Библиография:}

1. Багмет А.М., Бычков В.В. Квалификация и расследование преступлений, связанных с подкупом: учебное пособие. М., 2014. С. 19-22.

2. Алтухов С.А. Преступления сотрудников милиции (понятие, виды и особенности профилактики). СПб., 2001. С. 193.

3. Багмет А.М., Бычков В.В. Квалификация и расследование преступлений, связанных с подкупом: учебное пособие. М., 2014. С. 45.

4. Газимзянов Р.Р., Кабанов П.А. Основы профилактики коррупции в органах внутренних дел: учебная программа // Следователь. 2012. № 1(165). С. 6.

\section{References (transliterated):}

1. Bagmet A.M., Bychkov V.V. Kvalifikatsiya i rassledovanie prestuplenii, svyazannykh s podkupom: uchebnoe posobie. M., 2014. C. 19-22.

2. Altukhov S.A. Prestupleniya sotrudnikov militsii (ponyatie, vidy i osobennosti profilaktiki). SPb., 2001. S. 193.

3. Bagmet A.M., Bychkov V.V. Kvalifikatsiya i rassledovanie prestuplenii, svyazannykh s podkupom: uchebnoe posobie. M., 2014. S. 45.

4. Gazimzyanov R.R., Kabanov P.A. Osnovy profilaktiki korruptsii v organakh vnutrennikh del: uchebnaya programma // Sledovatel'. 2012. № 1(165). S. 6. 